Johannes Kabatek, University of Zürich

\title{
Comment on Göran Hammarström’s contribution
}

I would first like to explain the terms and arguments used in the call for this discussion forum. "Causal" and "final" were used in a philosophical and thus terminological sense, not referring to everyday usage, and evoking the Aristotelian differentiation of causes. The polemic statements on "standards" that are "generally accepted in sciences" are real quotations that I personally heard from linguists working with quantitative and psycholinguistic methods, colleagues claiming that methodological progress had changed the nature of the object itself: in former times, language studies had to rely, according to these colleagues, on intuitive ideas, but now experiments and quantitative analyses have made possible 'objective' judgements on language. I have not quoted any concrete author or statement or publication since I wanted to avoid a discussion with this or that individual researcher; the main idea of the forum was rather to open a general discussion.

I personally do absolutely not agree with these ideas and I think the object of linguistics has not changed at all and psycholinguistics and quantitative methods do not change the nature of the object. However, I believe that a fruitful integration of new methods can allow for progress in linguistics, ${ }^{1}$ but only under the condition that the nature of the object itself is recognized and new methods build on the fact that the intuition of the object in humanities is not an obstacle but an advantage for research. Linguists must take intuition consciously (and, of course, critically) into account.

The second remark is on the separation of synchrony and diachrony. It was not intended, as stated in Hammarström's text, that he discussion was "probably not meant to include synchronic problems". I do not believe - as Schuchardt did in his review of Saussure's Cours and as Coseriu does in $S D H$ - that it makes sense to consider the separation between synchrony and diachrony as a separation of objects. It is a purely methodological distinction, and it should maybe even be abandoned for methodology since methodology ought to be adequate with respect to its objects. Finality in 'diachrony' is only a particular perspective (a kind of historical projection) on the final character of human behaviour in general.

A third comment concerns the issue of the 'invisible hand'. I think that what Keller ${ }^{2}$ tried to show is that the idea that 'changes are entirely intentional' (p. 3) is as wrong as the opposite idea that 'changes are completely unconscious'. ${ }^{3}$ He wanted to show that the individual's goal was generally not to change the language but to communicate

1 See Kabatek, Johannes/Loureiro-Porto, Lucía (2013): "Mathematical models meet linguistic data and vice-versa”, International Journal of the Sociology of Language 221, 1-10. DOI 10.1515/ijsl-2013-0020

2 Keller, Rudi (1990): Sprachwandel. Von der unsichtbaren Hand in der Sprache, Tübingen, Francke (English version: On language change: The invisible hand in language, London/New York, Routledge, 1994).

3 There is a long tradition of statements claiming that language change is unconscious. When Saussure says "que la réflexion n'intervient pas dans la pratique d'un idiome ; que les sujets sont, dans une large mesure, inconscients des lois de la langue", (Ferdinand de Saussure, $C L G, 1916,106)$ he is just following that tradition. 
efficiently. An example: Speakers are frequently not openly aware of sound reduction processes in spoken language, but they reduce sounds due to whatever reason (call it economy, etc.). Sound change in language is considered, in Keller's view, as the sum of many individual intentional acts; the intention of the individual was to communicate as efficiently (and economically) as possible, the 'collective result' is sound change.

Now, there are two fundamental shortcomings in this conception: ${ }^{4}$ first, it cannot be denied that there exist cases of changes that are entirely intentional, where the speaker's aim is to change language, like in 'politically correct' usage or in collective purism. German 'Fräulein' is a word that has almost died out in a few decades due to conscious intervention of individuals and collective tabooization. Québec French 'fin de semaine' is preserved against 'weekend' in an almost general effort to avoid English influence.

The second shortcoming is more problematic: it consists in the idea that the sum of individual finalities creates a 'collective causality' and that the real issue of language change studies is to discover how this collective causality functions. In reality, such a collective causality is but the sum of individual finalities, and there is nothing more than the individual activity and the effect of its propagation (i.e. its adoption by other individuals) to be studied. If we want to know why there is a path in the garden, it does not make any sense to look at invisible hands: the path exists due to visible feet - and we should not look why these visible feet walk on the path but rather what the goal of the individuals is: where to they want to get? Which way is the shortest?

4 See also Kabatek, Johannes (2005): “Über Trampelpfade, sichtbare Hände und Sprachwandelprozesse”, in: Thomas Stehl (ed.): Unsichtbare Hand und Sprecherwahl. Typologie und Prozesse des Sprachwandels in der Romania, Tübingen: Narr, 155-174. 